\title{
PARTISIPASI PAGUYUBAN ONTHEL WISATA KOTA TUA DALAM PELESTARIAN KOTA TUAJAKARTA SEBAGAI DESTINASI WISATA
}

\author{
Adrianus Waranei Muntu \\ Hospitality dan Pariwisata, Universitas Bunda Mulia, Tangerang, amuntu@bundamulia.ac.id
}

\begin{abstract}
ABSTRAK:
Artikel ini menganalisis tentang partisipasi Paguyuban Onthel Wisata Kota Tua dalam pelestarianKota Tua sebagai destinasi wisata untuk mengetahui bentuk-bentuk partisipasi dan faktor-faktor yang mempengaruhi partisipasinya.Metode yang digunakan pada artikel ini adalah metode kualitatif dengan teknik pengumpulan data melalui wawancara, observasi, studi pustaka, dan studi dokumentasi.Data yang dikumpulkan dianalisis dengan teknik analisis deskriptif kualitatif, selanjutnya data disajikan secara formal dan informal.Isi pembahasan artikel ini memaparkan tentang bentukbentuk partisipasi paguyuban onthel yaitumembuat atraksi wisata, memperkenalkan atraksi wisata di Kota Tua, kerja bakti, mendirikan dan menjaga perpustakaan Kota Tua, menjaga pos informasi pariwisata, dan menyumbangkan ide.Faktor-faktor yang mempengaruhinya terbagi dalam dua jenis yaitu faktor pendukung dan faktor kendala. Artikel ini diharapkan dapat berkontribusi bagi pelestariandaya tarik wisata dan perkembangan pariwisata yang berkelanjutan di Jakarta pada umumnya, dan Kota Tua Jakarta pada khususnya.
\end{abstract}

Kata Kunci: Kota Tua, Jakarta, Partisipasi, Pariwisata, Paguyuban, Onthel, Destinasi Wisata

\begin{abstract}
:
This article analyzes the participation of the Kota Tua Onthel Tourism Association in preserving the Old City as a tourist destination to find out the forms of participation and factors that influence their participation. The method used in this article is a qualitative method with data collection techniques through interviews, observation, literature studies, and documentation studies. The data collected was analyzed with qualitative descriptive analysis techniques, then the data was presented formally and informally. The contents of the discussion of this article describe the forms of onthel community participation, namely making tourist attractions, introducing tourist attractions in Kota Tua, community service, establishing and maintaining the Old City library, maintaining tourism information posts, and contributing ideas. The factors that influence it are divided into two types, namely supporting factors and constraints. This article is expected to contribute to the preservation of tourist attractions and the
\end{abstract}


development of sustainable tourism in Jakarta in general, and the Old City of Jakarta in particular.

\section{Keywords: Old Town, Jakarta, Participation, Tourism, Community, Onthel, Tourist Destination}

\section{PENDAHULUAN \\ Latar Belakang}

Berwisatadi Indonesia saat ini telah menjadi tren bagi setiap kalangan dantidak lagi didominasi masyarakat kelas atas, tetapi juga menengah ke bawah. Masyarakat rela menyisihkan uang, khusus untuk biaya berwisata satu sampai empat kali dalam satu tahun. Bergesernya wisata dari kebutuhan tersier menjadi kebutuhan primer juga terlihat dari naiknya jumlah wisatawan nusantara.

Biasanya masyarakat perkotaan besar, terutama masyarakat Jabodetabek, sangat membutuhkan kegiatan ini untuk membuang rasa penat dari suasana ibukota yang kian hari kian padat. Dari segi ekonomi, mereka juga mampu untuk melakukan perjalanan wisata, setidaknya wisata dengan jarak tempuh yang tidak terlalu jauh seperti Bandung, Puncak, Anyer, dan sebagainya.

Melihat fenomena ini, Pemerintah Provinsi (Pemprov) DKI Jakarta ingin membuat masyarakatnya nyaman berwisata di kota mereka sendiri. Berbagai langkah dilakukan seperti renovasi, rehabilitasi, hingga revitalisasi berbagai destinasi wisata di ibukota. Salah satu destinasi wisata yang direvitalisasi adalah Kota Tua Jakarta.

Kondisi Kawasan Kota Tua Jakarta sendiri cukup menunjang untuk dijadikan pusat kegiatan dan wisata bagi masyarakat Jabodetabek. Aksesibilitas dan amenitas kawasan ini juga cukup baik karena letaknya dekat dengan pusat pemerintahan,banyaknya sarana transportasi, tersedia berbagai macam kuliner mulai dari kuliner khas Betawi dan daerah lain, kafe, restoran, hingga sarana akomodasi dari hotel kelas melati hingga hotel berbintang yang tersebar di berbagai penjuru Kota Tua.

Pembenahan dan revitalisasi fisik Kawasan Kota Tua Jakarta dilakukan Pemprov DKI melalui PT. Jakarta Old Town Revitalization Corps (JOTRC) yang merevitalisasi beberapa gedung di Kota Tua karena kondisi bangunan-bangunan di sini banyak yang terlihat memprihatinkan. Banyak bangunan tua peninggalan Belanda tersebut ditinggalkan, tidak dirawat dan terancam punah.

Pelestarian Kawasan Kota Tua telah berlangsung sejak sekitar 40-45 tahun lalu pada masa kepemimpinan Gubernur Ali Sadikin (1966-1977). Pada 2007, Gubernur Sutiyoso (1997-2007) kembali meresmikan revitalisasi Kota Tua. Tidak ketinggalan Gubernur Basuki (2014-2017) melanjutkan proses revitalisasi tersebut hingga selesai pada masa pemerintahan Gubernur Anies (2017-...). Tongkat estafet revitalisasi ini menunjukkan komitmen Pemprov DKI dari masa ke masa untuk membenahi kawasan tersebut.

Program ini adalah upaya pelestarian dan mempertahankan wujud secara fisik serta fungsinya sehingga mendekati pada keadaan semula tanpa mengabaikan aspek living monument yang sampai sekarang masih dimanfaatkan sesuai fungsi semula.Namun begitu, ternyata revitalisasi fisik Kawasan Kota Tua Jakarta yang dilakukan oleh Pemprov DKI ternyata bertolak belakang dengan revitalisasi nonfisiknya yang belum maksimal. Revitalisasi non-fisik yang dimaksud adalah sebuah 


\section{National Conference of Creative Industry: \\ Sustainable Tourism Industry for Economic Development}

Universitas Bunda Mulia, Jakarta, 5-6 September 2018 e-ISSN No: 2622-7436

proses menghidupkan kembali unsur-unsur sejarah, seni dan budaya setempat yang dihidupkan oleh para pemangku kepentingan setempat.

Kawasan Kota Tua memiliki banyak komunitas lokal baik yang kegiatannya berhubungan dengan unsur-unsur sejarah, seni dan budaya maupun tidak. Mereka yang bergerak melalui komunitas lokal yang lekat dengan unsur-unsur tersebut merupakan pemangku kepentingan yang cukup dominan dalam mengembangkan atraksi wisata di kawasan ini. Sebagian dari masyarakat lokalnya pun ada yang membentuk sebuah komunitas lokal, atau adapula yang bergabung ke dalam komunitas lokal yang lain.

Menurut Arida (2016: 35-36), pemberdayaan masyarakat melalui pariwisata berarti proses membangun dan mengembalikan kepercayaan diri masyarakat, bahwa mereka mampu membangun potensi alam dan budaya yang dimiliki untuk menjadi daya tarik wisata dalam memenuhi kebutuhan dasar, mencapai kehidupan yang lebih baik, dan terus berkembang secara berkelanjutan. Pemberdayaan pada dasarnya merupakan suatu proses yang dijalankan dengan kesadaran dan partisipasi penuh dari para pihak untuk meningkatkan kapasitas dan kapabilitas masyarakat sebagai sumber daya pembangunan agar mampu mengenali permasalahan yang dihadapi dalam mengembangkan dan menolong diri menuju keadaan yang lebih baik, mampu menggali dan memanfaatkan sumber daya yang tersedia untuk kepentingan diri dan kelompoknya, serta mampu mengeksistensikan diri secara jelas dengan mendapatkan manfaat darinya.

Kehadiran para komunitas lokal juga berpotensi untuk menarik wisatawan sehingga membuat kawasan ini juga ramai pada hari biasa bukan hanya pada akhir pekan. Banyak contoh aktivitas dari para komunitas lokal yang dapat menambah atraksi wisata di kawasan ini untuk menarik minat wisatawan yang datang seperti mengayuh sepeda onthel, mengikuti sinau membatik, berfoto bersama 'manusia batu' yang menyerupai karakter-karakter tokoh sejarah, dan berbagai kegiatan lainnya.

Dalam penelitian ini, tidak seluruh komunitas lokal akan diteliti. Komunitas yang paling dominan terlihat begitu kita tiba di Kawasan Kota Tua adalah Paguyuban Onthel Wisata Kota Tua. Komunitas ini merupakan paguyuban atau perkumpulan dari para pengayuh dan juru sewa sepeda di Taman Fatahillah dari sisi barat, utara, dan timur. Tidak jarang paguyuban onthel juga berperan sebagai frontliner Kota Tua terhadap wisatawan yang sedang berkunjung ke kawasan ini.

\section{Rumusan Masalah}

Pokok-pokok permasalahan di dalam penelitian ini adalah: 1) Bagaimana partisipasi Paguyuban Onthel Wisata Kota Tuadalam pelestarian Kota Tua sebagai sebuah destinasi wisata? 2) Faktor-faktor apa yang mempengaruhi partisipasi Paguyuban Onthel Wisata Kota Tua dalam pelestarian Kota Tua sebagai sebuah destinasi wisata?

\section{Tujuan Penelitian}

Secara umum, penelitian ini ditujukan untuk kemajuan dunia pariwisata di DKI Jakarta yang gencar mempromosikan slogan "Enjoy Jakarta" ke kancah nasional maupun internasional. Selain itu, peneliti berharap komunitas lokal di kawasan lain dapat berkembang dan mencontoh apa yang telah dilakukan oleh Paguyuban Onthel Wisata Kota Tua.

Secara khusus, penelitian ini bertujuan untuk mengetahui bentuk partisipasi Paguyuban Onthel Wisata Kota Tua dalam pelestarian Kota Tua sebagai sebuah destinasi wisata dan faktor-faktor yang mempengaruhinya. 


\section{National Conference of Creative Industry: \\ Sustainable Tourism Industry for Economic Development}

Universitas Bunda Mulia, Jakarta, 5-6 September 2018 e-ISSN No: 2622-7436

\section{TINJAUAN PUSTAKA \\ Landasan Teori}

Teori yang dipergunakan dalam penelitian ini adalah Teori Community Based Tourism (CBT)atau Pariwisata Berbasis Masyarakat dan Teori Partisipasi. Dari berbagai Teori Pariwisata Berbasis Masyarakat dan Teori Partisipasi, yang hanya dipergunakan pada penelitian kali ini adalah teori menurut Tosun serta Richard dan Hall. Selain itu, pemahaman mengenai atraksi wisata juga akan dibahas pada kolom ini.

Menurut Richards dan Hall (dalam Putra, 2015: xiv), Teori Pariwisata Berbasis Masyarakat erat kaitannya dengan sustainable tourism development (pembangunan pariwisata berkelanjutan). Keduanya memberikan pengutamaan pada manfaat pembangunan bagi masyarakat, khususnya manfaat ekonomi, sosial budaya, dan lingkungan. Apabila masyarakat tidak mendapatkan manfaat-manfaat tersebut, belum tentu masyarakat akan turut berpartisipasi. Pembangunan pariwisata pada destinasi tersebut pun belum tentu dapat bertahan dalam waktu yang lama atau berkelanjutan.

Terkait Teori Partisipasi, Tosun (dalam Madiun, 2010: 8) mengemukakan bahwa partisipasi masyarakat dapat dipandang sebagai suatu istilah yang dapat dibagi menjadi beberapa kategori, di mana berbagai kelompok yang berkepentingan ikut berpartisipasi dalam pembangunan pariwisata dengan berbagai cara yang disesuaikan dengan kemampuan kelompok itu sendiri.

Tosun (dalam Madiun, 2010: 18) menjelaskan bahwa partisipasi masyarakat dibagi dalam tiga tipologi, yaitu: 1) Partisipasi spontan (spontaneous participation) adalah partisipasi masyarakat yang terjadi secara sukarela, tanpa didorong oleh pihak luar. Bentuk ini merupakan bentuk yang ideal dari partisipasi masyarakat. 2) Partisipasi terdorong (induced participation) partisipasi masyarakat yang terjadi karena adanya dukungan, perintah dan secara resmi disetujui. Jenis partisipasi ini paling sering ditemui di negara-negara berkembang, dimana pemerintah memiliki peran utama untuk memulai aksi partisipatif melalui strategi-strategi untuk mendorong dan melatih pemimpin lokal agar mengambil peran memimpin, membangun, kerjasama dan mendukung masyarakat. 3) Partisipasi terpaksa (coercive participation) adalah partisipasi masyarakatyang terjadi karena masyarakat diwajibkan dan dimanipulasi oleh pihak penguasa untuk terlibat dalam pengembangan. Bentuk partisipasi ini adalah yang paling ekstrem.Dalam jangka pendek mungkin ada hasil secara langsung.Namun dalam jangka panjang, partisipasi ini berpotensi kehilangan dukungan dari masyarakat, tidak menghasilkan bahkan mengikis minat masyarakat unstuk terlibat dalam aktivitas pengembangan.

Berikutnya adalah pemahaman mengenai destinasi wisata. Menurut Pitana (2009), destinasi wisata adalah suatu tempat yang dikunjungi dengan periode waktu yang cukup signifikan selama masa perjalanan seseorang jika dibandingkan dengan tempat lainnya yang dilalui selama perjalanan. Apabila dikaitkan dengan penelitian ini, dapat disimpulkan bahwa destinasi wisatanya adalah Kota Tua. Sementara itu, Paguyuban Onthel Wisata Kota Tua merupakan salah satu stakeholder Kota Tua yang hendak berpartisipasi dalam melestarikan destinasi wisata terkait.

\section{Kerangka Pemikiran}

Berdasarkan permasalahan yang ada, penulis tertarik untuk melakukan penelitian yang fokus pada partisipasi dari Paguyuban Onthel Wisata Kota Tua sebagai sebuah atraksi wisatadi Kawasan Kota Tua Jakarta baik bentuk-bentuk partisipasinya danfaktor-faktor yang mempengaruhinya.Model penelitian mengenai penelitian ini dapat dilihat pada gambar berikut: 


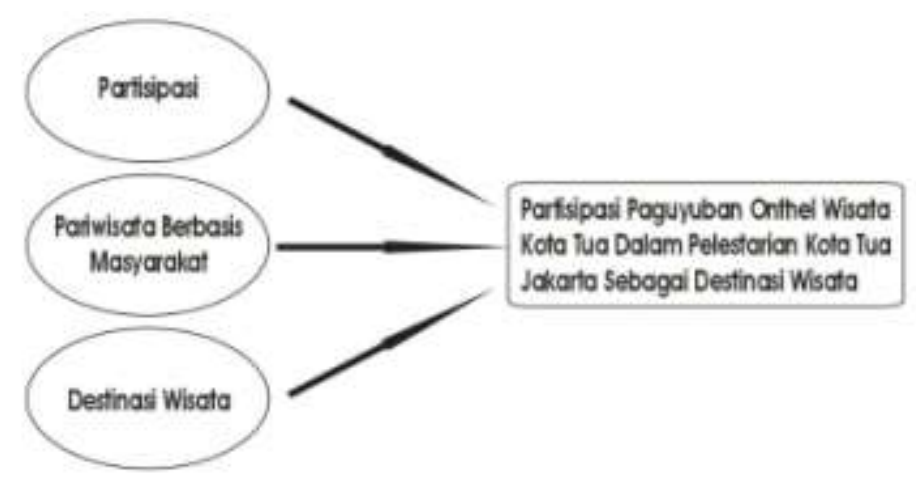

Gambar 1 Kerangka Pemikiran

Sumber: $\quad$ Peneliti

\section{METODE PENELITIAN}

Jenis dan Sumber Data

Di dalam penelitian ini, data yang dipergunakan adalah data kualitatif. Data kualitatif yang dikumpulkan dalam penelitian ini adalah informasi terkait keterlibatan paguyuban onthel di Kota Tua, pendapat pemangku kepentingan pariwisata terkait partisipasi paguyuban onthel, kontribusi-kontribusi paguyuban ontheldi kawasan tersebut, dan peraturan daerah (Perda) mengenai kepariwisataan.

Selain itu, ada 2 jenis sumber yang digunakan di dalam penelitian ini yaitu sumber primer dan sumber sekunder. Sumber primer pada penelitian ini adalah buktibukti tertulis pertama dalam bentuk brosur, catatan dari anggota paguyuban onthel, serta wawancara. Sedangkan sumber sekundernya adalah hampir seluruh tulisan ilmiah yang diterbitkan seperti buku dan artikel-artikel terkait Kota Tua dan Paguyuban Onthel Wisata Kota Tua.

\section{Analisis Data}

Data yang diperoleh dengan teknik observasi, wawancara, studi pustaka, dan studi dokumen dalam penelitian ini selanjutnya dianalisa dengan teknik analisis deskriptif kualitatif. Proses analisis data dengan teknik analisis deskriptif kualitatif dalam penelitian ini adalah sebagai berikut: a) Reduksi Data, dimana data-data yang telah diambil dari observasi, wawancara, studi pustaka, dan studi dokumen mengenai paguyuban onthel dan hal-hal yang berkaitan dengan penelitian ini telah disaring. b) Penyajian Data, dimaksudkan agar lebih mempermudah bagi penulis untuk dapat melihat gambaran secara keseluruhan atau bagian-bagian tertentu dari data penelitian. c) Penarikan Kesimpulan, dalam tahapan ini, data yang telah direduksi dan disajikan selanjutnya dibuat kesimpulan, dengan demikian kesimpulan dalam penelitian kualitatif dapat menjawab rumusan masalah dalam penelitian ini.

\section{HASIL PENELITIAN DAN PEMBAHASAN}

\section{Gambaran Umum Paguyuban Onthel Wisata Kota Tua}

PaguyubanOnthel Wisata Kota Tua merupakan sebuah komunitas pecinta dan juru sewa sepeda onthel yang kesehariannya beraktivitas di Taman Fatahillah. Aktivitas utama mereka adalah menyewakan sepeda onthel kepada para wisatawan. Paguyuban atau komunitas ini sangat mudah ditemui oleh para wisatawan karena sepeda onthel mereka berdiri berjajar padasudut barat, utara, dan timur di Taman Fatahillah. 


\section{National Conference of Creative Industry: \\ Sustainable Tourism Industry for Economic Development}

Universitas Bunda Mulia, Jakarta, 5-6 September 2018

e-ISSN No: 2622-7436

Merk sepeda onthel yang mereka pergunakan bervariasi mulai dari Raleigh, Fongers, Burgers, Simplex, dan Gazelle. Merk sepeda onthel yang paling banyak ditemukan pada paguyuban ini adalah Raleigh. Paguyuban ini pun mendapatkan sepedasepeda onthel tersebut dari berbagai sumber, terutama yang berasal dari berbagai daerah di pulau Jawa (Mulyono, 18 Oktober 2016).

Cikal bakal paguyuban ini berasal dari komunitas penarik sepeda onthel yang belum memiliki nama sejak 2008. Mereka hanya terdiri dari komunitas penarik sepeda onthel yang menyewakan sepedanya kepada wisatawan. Pada 2009, komunitas ini baru memiliki ketua yaitu Tarmuji. Kepemimpinannya hanya berlangsung hingga 2012 karena Tarmujimenghadap Yang Maha Kuasa lebih awal.

Pada masa kepemimpinan Tarmuji dengan dibantu oleh Tim DMO Kota Tua, para penarik sepeda onthel mulai berbenah dan mengembangkan perkumpulannya agar memiliki struktur organisasi (Mulyono, 18 Oktober 2016). Tahun 2012, atas rekomendasi Tim DMO Kota Tua, komunitas ini akhirnya bertransformasi menjadi Paguyuban Onthel Wisata Kota Tua (Riadi, 21 September 2016). Kini paguyuban ini telah menjadi bagian dari Forum Komunikasi Tata Kelola Pariwisata Kota Tua (FTKPKT) yang didirikan oleh DMO Kota Tua.

Berdasarkan keterangan di atas, paguyuban ini berpartisipasi dalam membuat atraksi baru di Kota Tua dengan memajang serta menawarkan jasa sepeda onthelnya. Jenis partisipasi mereka termasuk dalam partisipasi terdorong (induced participation) karena pendirian komunitas dipengaruhi oleh pihak Tim DMO Kota Tua. Walaupun begitu, cikal bakal sebelum menjadi paguyuban adalah karena persamaan minat dalam menyukai sepeda onthel serta keinginan mereka mencari rezeki sekaligus membangun Kota Tua lewat sepeda onthelnya.

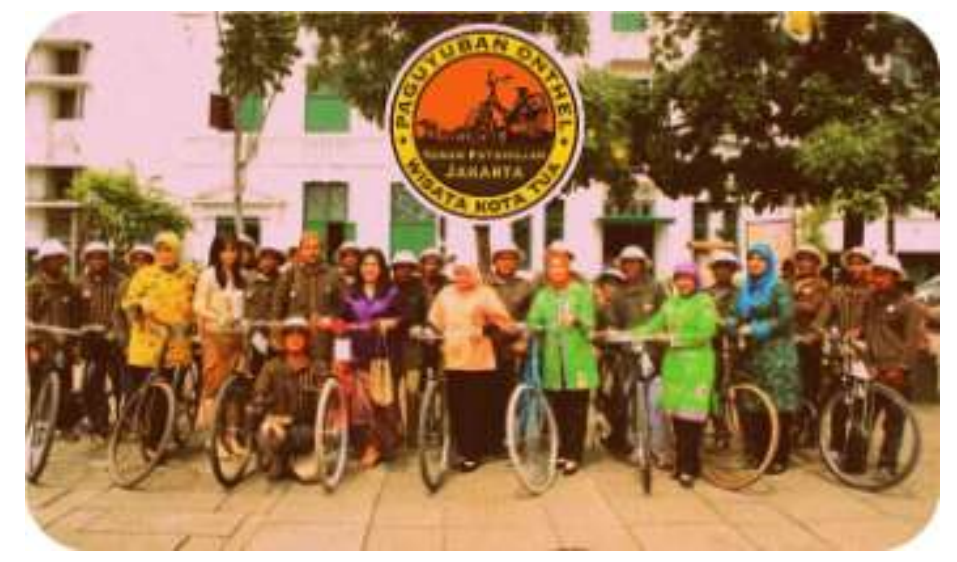

Gambar 2 Paguyuban Onthel Wisata Kota Tua bersama Iriana Widodo (berpakaian warna ungu) di depan Museum Wayang, sebelah barat Taman Fatahillah

Sumber: $\quad$ Fan page Paguyuban Onthel Wisata Kota Tua

Perbedaan paguyuban onthel ini dengan pengayuh sepeda onthel di tempat lain di Kota Tua adalah pada sistemnya. Paguyuban ini menerapkan sistem self-service, yaitu para wisatawan mengayuh sendiri sepeda onthel yang telah disewa untuk mengelilingi Taman Fatahillah, meskipun sepeda onthel milik paguyuban ini dapat pula dipergunakan untuk kebutuhan pre-wedding dan wisata keliling Kota Tua. Sedangkan para pengayuh sepeda onthel di luar paguyuban ini biasanya menggunakan sepeda onthelnya untuk keperluan mencari dan mengantarkan penumpang seperti ojek. 


\section{National Conference of Creative Industry: \\ Sustainable Tourism Industry for Economic Development}

Universitas Bunda Mulia, Jakarta, 5-6 September 2018 e-ISSN No: 2622-7436

Paguyuban ini menyadari bahwa kualitas jauh lebih penting daripada kuantitas. Mereka tidak ingin memiliki anggota yang hanya membuat kegaduhan sehingga mereka membatasi keanggotaan. Untuk membedakan mana onthel yang menjadi anggota paguyuban atau bukan, mereka mengenakan seragam khusus. Pada awal berdiri hingga 2011, mereka mengenakan rompi biru. Setelah itu mereka menggantinya dengan rompi coklat (Antara News, 2013).

Mereka hanya memiliki 38 anggota dan semuanya mendapatkan pelatihan bahasa Inggris dari DMO Kota Tua. Jumlah ini merupakan jumlah yang ideal menurut mereka. Mereka beranggapan bahwa tidak baik menambah anggota yang terlalu banyak. Mereka lebih suka jikalau paguyuban ini beranggotakan sedikit namun solid.

Paguyuban Onthel Wisata Kota Tua kini telah tumbuh menjadi komunitas yang solid dalam mengembangkan dunia pariwisata di Kota Tua Jakarta. Kehadiran mereka telah memberikan kontribusi positif dengan menambah variasi atraksi wisata di kawasan ini selain daripada mereka telah mendapatkan manfaat ekonominya. Bukan tidak mungkin bahwa dalam beberapa tahun kedepan, sepeda-sepeda onthel ini menjadi salah satu icon utama Kota Tua yang kehadirannya selalu diminati oleh para wisatawan nusantara maupun mancanegara yang datang.

\section{Bentuk-Bentuk Partisipasi Paguyuban Onthel Wisata Kota Tua Membuat Atraksi Wisata Baru}

Bentuk partisipasi Paguyuban Onthel Wisata Kota Tua yang utama adalah penciptaan sebuah atraksi baru, berupa penyewaan sepeda onthel, yang sebelumnya belum nampak di kawasan ini. Wisatawan yang datang dapat dengan mudah menyewa sepeda onthel yang mereka pajang di sisi barat, utara, dan timur dari Taman Fatahillah.

Biaya sewa sepeda onthel yang ditetapkan bervariasi. Untuk menyewa sepeda selama 30 menit dikenakan biaya $\mathrm{Rp}$ 20.000, 1 jam dikenakan biaya $\mathrm{Rp}$ 40.000.Apabila ada yang ingin menyewa sepeda onthel selama satu hari penuh, dikenakan biaya $\mathrm{Rp}$ 150.000.Biaya sewa juga sudah termasuk topi bulat layaknya warga Eropa masa kolonial serta topi ala noni Belanda bagi wanita untuk dipakai sementara saat mengendarai sepeda.Secara tidak langsung, mereka berjasa dalam memunculkan sebuah atraksi wisata baru karena wisatawan menjadi memiliki banyak pilihan atraksi wisata untuk dinikmati, bukan hanya museum atau atraksi-atraksi wisata lainnya.

\section{Memperkenalkan Atraksi Wisata Lain}

Paguyuban onthel juga berpartisipasi dalam memperkenalkan berbagai atraksi wisata di Kota Tua baik museum, bangunan-bangunan tua bersejarah, pertunjukan kesenian. Paguyuban ini juga dapat memandu wisatawan untuk mengunjungi beberapa daya tarik wisata seperti Pelabuhan Sunda Kelapa, Museum Bahari, Menara Syahbandar, Jembatan Kota Intan, dan Toko Merah selama 2 jam.

17 dari 38 anggotanya pernah mengikuti bimbingan teknis pramuwisata yang diadakan Himpunan Pramuwisata Indonesia (HPI) DKI Jakarta (Antara News, 2013). Walaupun begitu, hanya 7 orang yang ditunjuk oleh paguyuban yang dapat menjadi pemandu dan dua di antaranya dapat memandu dalam bahasa Inggris. Selain itu, jasa mereka juga kerapkali dipergunakan oleh pihak-pihak yang telah membuat paket wisata di Kota Tua. 


\section{National Conference of Creative Industry: \\ Sustainable Tourism Industry for Economic Development}

Universitas Bunda Mulia, Jakarta, 5-6 September 2018

e-ISSN No: 2622-7436

\section{Kerja Bakti}

Setiap akhir pekan, tepatnya Jumat, Sabtu, Minggu, dan hari besar nasional selalu diselenggarakan kegiatan kerja bakti oleh komunitas-komunitas yang beraktivitas di sekitar Taman Fatahillah. Kegiatan mereka ini awalnyadimotori oleh paguyuban onthel.Bagi yang tidak mengikuti kerja bakti, tidak boleh beraktivitas lagi di sekitar kawasan ini (Tempo, 2015).

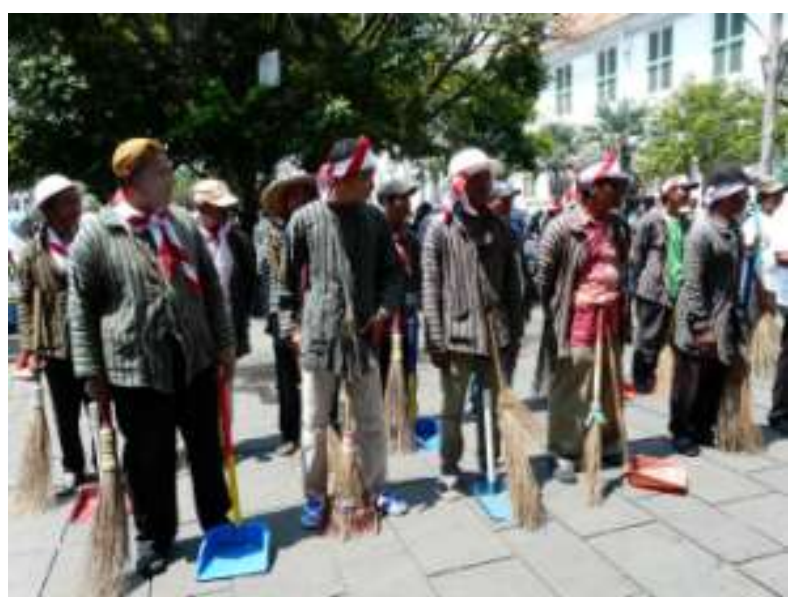

Gambar 3 Aksi Bersih-Bersih Taman Fatahillah oleh paguyuban onthel Sumber: $\quad$ Koleksi Tim DMO Kota Tua Jakarta

\section{Mendirikan dan Menjaga Perpustakaan Kota Tua}

Sejak tahun 2014, Taman Fatahillah telah memiliki ruang baca umum yang dapat dinikmati wisatawan. Ruang baca ini diisi oleh berbagai macam jenis buku mulai dari buku sekolah hingga buku sejarah dan kebudayaan Indonesia.Setelah pendirian, paguyuban onthel dan beberapa pemangku kepentingan Kota Tua lainnya langsung menangani perpustakaan ini dan dipimpin oleh Supriyanto, mantan Ketua Paguyuban Onthel Wisata Kota Tua. Yang berjaga di perpustakaan ini adalah anggota-anggota dari paguyuban onthel secara bergantian setiap 2 jam. Apabila ada pengunjung yang datang, anggota paguyuban onthel

\section{Piket Menjaga Pos Informasi Pariwisata}

Kawasan Inti memiliki 3 Pos Informasi Pariwisata yang terbagi di wilayah utara, barat, dan timur dari Taman Fatahillah. Pos bagian timur merupakan tanggung jawab UPK Kota Tua, pos bagian utara adalah tanggung jawab RW 06 Kelurahan Pinangsia, dan pos bagian barat adalah tanggung jawab FTKPKT.

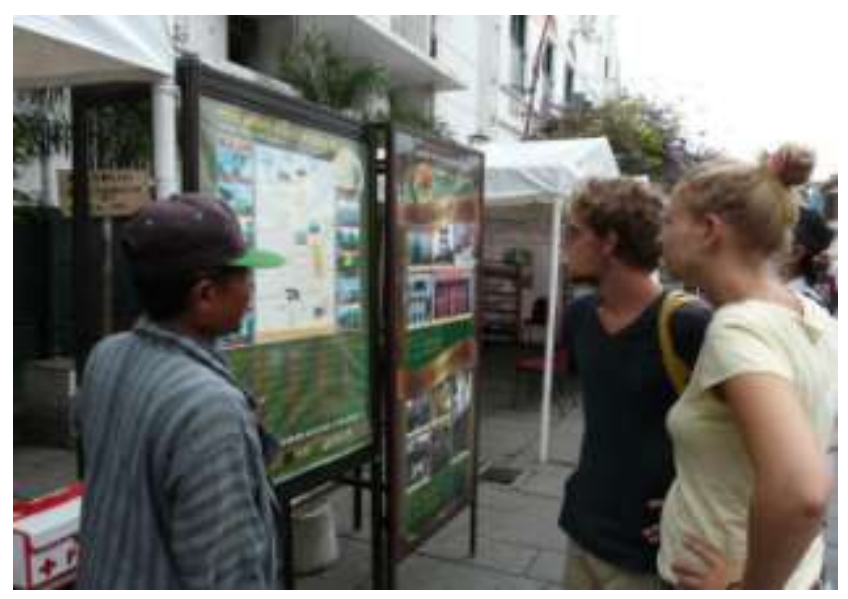


Gambar 4 Salah satu anggota Paguyuban Onthel Wisata Kota Tua sedang memberikan informasi kepada wisatawan mancanegara (wisman) saat piket penjagaan pos informasi pariwisata di Taman Fatahillah

Sumber: $\quad$ Koleksi Tim DMO Kota Tua Jakarta

Pos Informasi Pariwisata di sebelah barat yang merupakan tanggung jawab FTKPKT dikelola secara gotong royong oleh komunitas-komunitas yang ada di Taman Fatahillah terutama Paguyuban Onthel Wisata Kota Tua, Komunitas Manusia Batu, dan Perguruan Pencak Silat Cakra Buana. Selain komunitas-komunitas tersebut, turut membantu pula Karang Taruna dan Pramuka Museum Mandiri.

\section{Menyumbangkan Ide}

Forum Tata Kelola Pariwisata Kota Tua (FTKPKT) yang terdiri dari semua pemangku kepentingan di Kota Tua Jakarta telah menjadi wadah yang strategis untuk beraspirasi maupun komunikasi. FTKPKT dipimpin oleh Kepala UPK Kota Tua Jakarta yang sedang menjabat dimana pada tahun 2016 kepalanya adalah Norviadi Setyo Husodo. FTKPKT telah berkali-kali mengadakan pertemuan untuk membahas masalah dan solusi di Kota Tua.

Di dalam setiap pertemuan yang digelar oleh FTKPKT, muncul berbagai ide dan gagasan untuk kemaslahatan Kota Tua. Penyampaian ide dan gagasan ini berjalan lebih cair karena berada di dalam forum (Riadi, 21 September 2016). Ide yang paling mencolok adalah ide yang disampaikan oleh paguyuban onthel mengenai penataan PKL (Pedagang Kaki Lima) di Kota Tua.

Menurut paguyuban onthel, keberadaan PKL mempersempit ruang gerak bagi wisatawan yang ingin menyewa onthel dan mengganggu kebersihan Kota Tua. Menurut mereka seharusnya area Taman Fatahillah dan sekitarnya steril dari hal-hal destruktif seperti ini (Mulyono, 2 Januari 2016). Di dalam pertemuan FTKPKT, saran ini diteruskan kepada Sudin UMKM Jakarta Barat. Ide dan gagasan lain juga kerapkali diteruskan kepada pihak berwenang yang terkait.

\section{Faktor-Faktor Yang Mempengaruhi Partisipasi Paguyuban Onthel Wisata Kota Tua \\ Faktor-Faktor Pendukung}

Faktor utama paguyuban onthel adalah karena termotivasi untuk memperoleh manfaat ekonomi. Kebutuhan ekonomi merupakan kebutuhan dasar setiap manusia untuk bertahan hidup. Pemenuhan kebutuhan tersebut memerlukan langkah-langkah dan tindakan, salah satunya adalah yang dilakukan oleh paguyuban onthel. Indikasinya adalah karena mereka sehari-hari beraktivitas di Kawasan Kota Tua untuk menunggu pengunjung yang datang menggunakan jasa mereka.

Hal ini diakui oleh mereka bahwa mereka sendiri yang berinisiatif memilih pekerjaan untuk menyewakan sepeda onthel kepada pengunjung Kota Tua. Alasan mereka menyewakan sepeda onthel adalah karena ingin menyesuaikan dengan citra Kota Tua dan pekerjaan ini lebih bebas tanpa terikat oleh apapun (Mulyono, 18 Oktober 2016). 


\section{National Conference of Creative Industry: Sustainable Tourism Industry for Economic Development}

Universitas Bunda Mulia, Jakarta, 5-6 September 2018 e-ISSN No: 2622-7436

Motivasi ini telah diketahui oleh semua pihak, termasuk UPK Kota Tua.Pihak UPK Kota Tua membenarkan dan mendukung paguyuban ontheluntuk memperoleh manfaat ekonomi dari Kota Tua. Walaupun begitu, UPK Kota Tua tidak mendukung apabila manfaat ekonomi yang ingin dicapai oleh paguyuban onthel di atas batas kewajaran karena hal tersebut dapat berdampak buruk terhadap citra Kota Tua Jakarta yang dikelola oleh Pemprov DKI Jakarta (Husodo, 8 Maret 2016).

Faktor berikutnya yang mempengaruhi adalah adanya keramaian wisatawan yang berkunjung ke Kota Tua Jakarta.Wilayah di Kota Tua yang paling ramai dikunjungi adalah Kawasan Inti yang berada di sekitar Taman Fatahillah.Berdasarkan hasil pantauan penulis, Kawasan Inti Kota Tua mulai dipadati wisatawan di akhir pekan pada saat menjelang sore hari pada hari Sabtu, dan sejak siang hari pada hari Minggu. Berbagai macam aktivitas dilakukan oleh para wisatawan yang meramaikan kawasan ini yaitu berfoto, berkeliling taman menggunakan sepeda onthel, atau bahkan hanya duduk memandangi bangunan-bangunan tua dan bersenda gurau dengan kawanannya.

Setelah keramaian, faktor lainnya adalah adanya dukungan parastakeholder di Kota Tua.Berbagai bentuk dukungan dan kerjasama yang diberikan oleh stakeholderkepada paguyuban onthel selaku salah satu komunitas di Kota Tua adalahcommunity development oleh UPK Kota Tua Jakarta, dukungan Kementerian Pariwisata dan Ekonomi Kreatif (Kemenparekraf) RI lewat DMO Kota Tua Jakarta, keterlibatan masyarakat lokal, keterbukaan kafe dan restoran di Kota Tua dan mengajak kerjasama

Kerjasama antar komunitasjuga menjadi faktor penting yang mempengaruhi partisipasi paguyuban onthel. Contoh kerjasama antar komunitas yang pernah terjalin adalah kerjasama antara Komunitas Jelajah Budaya dan Paguyuban Onthel Wisata Kota Tua. KJB kerapkali mengajak paguyuban onthel untuk berpartisipasi di dalam beberapa kegiatannya yang mengelilingi Kota Tua. Di dalam beberapa kegiatan tersebut, para peserta kegiatan KJB menumpang sepeda yang dikendarai para anggota paguyuban onthel untuk berkeliling Kota Tua di bawah panduan KJB (Setiawan, 31 Mei 2016).

Komunitas lokal lain yang menyadari akan pentingnya kerjasama ini adalah Komunitas China Town Art and Culture. Komunitas ini mengajak Komunitas Manusia Batu dan Paguyuban Onthel Wisata Kota Tua untuk berpartisipasi di dalam acara tahunannya yaitu Kirab Budaya. Di dalam acara ini, paguyuban onthel diajak untuk berkeliling mengikuti kirab, sedangkan Kombat posisinya berada di bazaar atau di sekitar panggung (Prayitno, 25 Juli 2016).

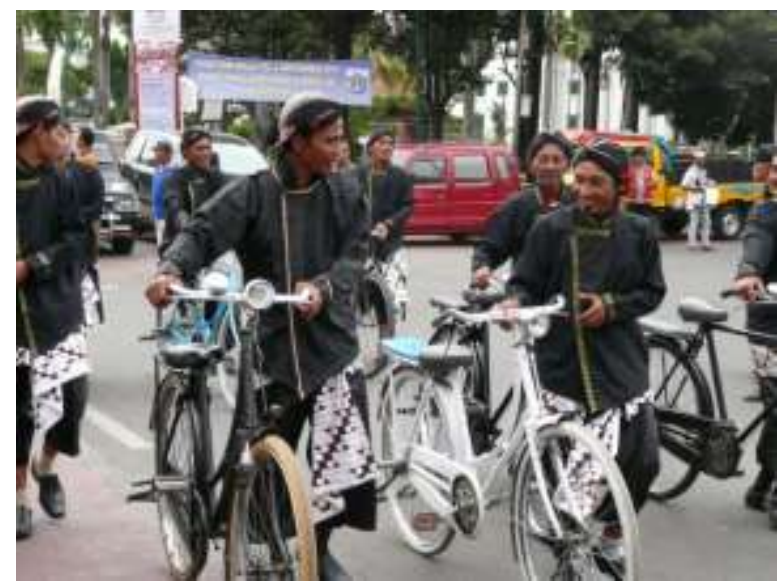




\section{National Conference of Creative Industry: Sustainable Tourism Industry for Economic Development}

Universitas Bunda Mulia, Jakarta, 5-6 September 2018 e-ISSN No: 2622-7436

Gambar 5 Partisipasi Paguyuban Onthel Wisata Kota Tua dalam Kirab Budaya yang diadakan oleh Komunitas China Town Art and Culture

Sumber: $\quad$ Koleksi Tim DMO Kota Tua Jakarta

Faktor terakhir yang tidak kalah penting adalah maraknya penggunaan media sosial di Indonesia. Hampir seluruh media sosial memunculkan fenomena bahwa kalangan pemuda gemar untuk mengekspresikan dirinya dan mengunggah aktivitasaktivitas yang mereka lakukan termasuk kegiatan wisata dalam bentuk foto dan video di media sosial. Kalangan pemuda yang berkunjung ke Kota Tua pun melakukan hal yang sama.

Fenomena tersebut yang menyebabkan paguyuban onthel eksis di kawasan ini.Paguyuban Onthel Wisata Kota Tua memanfaatkannya dengan mengimprovisasi warna dari sepeda-sepeda onthel mereka agar lebih menarik untuk dijadikan objek foto.

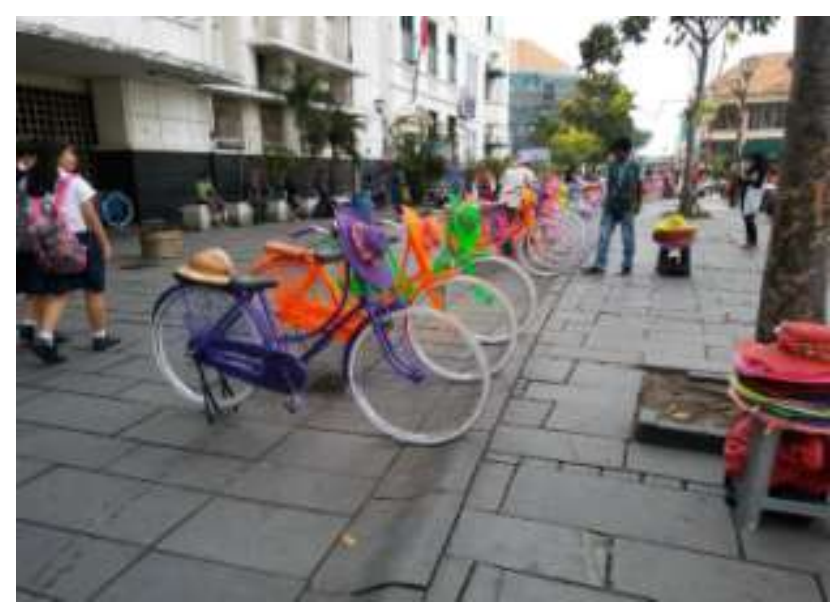

Gambar 6 Sepeda onthel milik Paguyuban Onthel Wisata Kota Tua yang warnanya bervariasi

Sumber: $\quad$ Koleksi pribadi penulis

\section{Faktor-Faktor Kendala}

Faktor kendala utama yang mempengaruhi partipasi paguyuban onthel adalah belum jelasnya status mereka di Kota Tua. Meskipun berperan aktif dalam pengembangan atraksi wisata di Kota Tua Jakarta, ternyata status mereka di kawasan ini masih dipertanyakan.Status yang dimaksud adalah pengakuan dari Pemprov DKI berupa sebuah regulasi yang diberikan kepada komunitas lokal. Sejak mereka berkegiatan di Kota Tua, regulasi Pemprov DKI mengenai para komunitas lokal belum jelas.

Belum jelasnya status tersebut juga menyebabkan kontroversi di kalangan Pemprov DKI, salah satu contohnya adalah pro dan kontra terhadap eksistensi Paguyuban Onthel Wisata Kota Tua terkait peraturan daerah (Perda) mengenai penertiban kawasan. Perda yang membuat eksistensi paguyuban onthel menjadi kontroversi adalah Perda No. 8 Tahun 2007Tentang Ketertiban Umum.

Perda No. 8 Tahun 2007 Tentang Ketertiban Umum Pasal 25 membahas para pedagang kaki lima yang dilarang untuk membuka usaha pada fasilitas-fasilitas umum seperti bagian jalan/trotoar, halte, jembatan penyeberangan orang, dan tempat-tempat umum lainnya, kecuali pada jalan/trotoar dan tempat-tempat kepentingan umum yang ditetapkan oleh Gubernur DKI Jakarta. 


\section{National Conference of Creative Industry: \\ Sustainable Tourism Industry for Economic Development}

Universitas Bunda Mulia, Jakarta, 5-6 September 2018 e-ISSN No: 2622-7436

Pasal tersebut menjadi landasan bagi mereka yang kontra untuk menyamakan paguyuban onthel dengan pedagang kaki lima di Kawasan Kota Tua. Pandangan ini terjadi karena masih adanya stigma bahwa paguyuban onthel, dan mungkin komunitaskomunitas lokal lainnya, merupakan parasit yang perlu dibersihkan dari kawasan ini. Mereka yang kontra menginginkan seluruh Kawasan Kota Tua bersih tanpa memperhitungkan bahwa kawasan ini adalah kawasan pariwisata yang hidup salah satunya karena ada komunitas lokal tersebut.

Stigma tersebut bertolak belakang dengan pandangan mereka yang pro terhadap eksistensi paguyuban onthel di Kota Tua. Mereka yang pro menganggap paguyuban onthel sebagai sebuah unsur yang berbeda dengan pedagang kaki lima. Eksistensi paguyuban onthel dianggap menambah variasi atraksi wisata kawasan ini yang perlu dilestarikan.

Pro dan kontra terhadap eksistensi Paguyuban Onthel Wisata Kota Tua terkait peraturan daerah (Perda) seperti yang telah dipaparkan di atas membuat paguyuban onthel rawan disterilkan dari Kawasan Kota Tua. Paguyuban onthel hampir disterilkan dari Taman Fatahillah pada tahun 2012. Namun berkat dukungan dan kerjasama dari pemangku kepentingan lainnya, sepeda-sepeda onthel milik paguyuban ini masih dapat dinikmati wisatawan.

Faktor kendala lainnya adalah kurangnya manajemen media sosial paguyuban onthel. Media sosial terbukti berguna untuk meningkatkan komunikasi antara paguyuban ontheldengan masyarakat,meningkatkan brand awareness, serta menghemat biaya pemasaran dan promosi.Paguyuban onthel juga memanfaatkan media sosial sebagai sarana pemasaran dan promosinya walaupun belum dimaksimalkan secara keseluruhan.

Paguyuban ini hanya menggunakan facebook sebagai sarana informasi aktivitas mereka melalui media sosial. Fitur facebook yang digunakan adalah fan page, group, dan akun personal. Fan page paguyuban ini tidak aktif terhitung sejak Januari 2016 dan informasi tentang paguyuban pun tidak mendetail. Yang masih aktif adalah group walaupun terkadang isinya tidak kontekstual dan akun personal yang kurang detail dalam memberikan gambaran mengenai paguyuban.

Keterangan-keterangan tersebut menunjukkan bahwa paguyuban tidak terlalu menjadikan media sosial sebagai sarana informasi aktivitasnya yang utama. Mereka lebih mengandalkan promosi melalui media-media yang meliput mereka, atau sistem pemasaran 'mulut ke mulut' dari orang-orang yang pernah berkunjung ke Taman Fatahillah.

Terakhir, faktor kendala yang terjadi adanya konflik internal. Konflik merupakan situasi yang wajar terjadi dalam setiap perkumpulan. Paguyuban onthel sebagai sebuah perkumpulan juga pernah mengalami hal yang sama karena berbagai macam penyebab seperti kemampuan berorganisasi, cara berpikir, dan konflik kepentingan.Salah satu contoh konflik di paguyuban ini adalah akibat adanya peraturan dimana setiap anggota hanya boleh mengeluarkan dua unit sepeda onthel untuk disewakan kepada wisatawan. Namun beberapa anggota ada yang mengeluarkan lebih dari dua unit sepeda onthel. Hal ini menimbulkan kecemburuan dan rasa ketidakadilan dari anggota lain. Anggota yang bersangkutan pun tidak mengindahkan teguran yang diberikan oleh ketua dan anggota lain. 


\section{National Conference of Creative Industry: \\ Sustainable Tourism Industry for Economic Development}

Universitas Bunda Mulia, Jakarta, 5-6 September 2018 e-ISSN No: 2622-7436

\section{SIMPULAN DAN SARAN \\ Simpulan}

Berdasarkan hasil dan pembahasan yang telah dipaparkan, dapat disimpulkan dua hal. Yang pertama mengenai bentuk-bentuk partisipasi Paguyuban Onthel Wisata Kota Tua dalam pelestarian Kota Tua sebagai sebuah destinasi wisata. Bentuk-bentuk partisipasinya yaitu membuat atraksi wisata baru berupa penyewaan sepeda onthel, memperkenalkan berbagai atraksi wisata di Kota Tua, kerja bakti, mendirikan dan menjaga perpustakaan Kota Tua, piket menjaga pos informasi pariwisata, dan menyumbangkan ide-ide bagi perkembangan Kota Tua Jakarta.

Kedua adalah mengenai faktor-faktor yang mempengaruhi partisipasi Paguyuban Onthel Wisata Kota Tua dalam pelestarian Kota Tua sebagai sebuah destinasi wisata. Faktor-faktor tersebut dibagi menjadi faktor-faktor pendukung dan faktor-faktor kendala. Faktor pendukungnya adalah motivasi untuk memperoleh manfaat ekonomi, adanya keramaian wisatawan yang berkunjung ke Kota Tua Jakarta, adanya dukungan parastakeholder di Kota Tua, kerjasama antar komunitas, dan maraknya penggunaan media sosial di Indonesia. Sedangkan untuk faktor-faktor kendalanya adalah belum jelasnya status mereka di Kota Tua, kurangnya manajemen media sosial paguyuban, dan adanya konflik internal

\section{Saran}

Berdasarkan hasil dan pembahasan yang telah dipaparkan, penulis memberikan beberapa saran. Yang pertama adalah bagi para peneliti selanjutnya. Para peneliti selanjutnya dapat mengkaji perkembangan fasilitas pendukung (amenity) pariwisata di Kota Tua Jakarta yang sekiranya menunjang partisipasi para paguyuban onthel. Para peneliti juga diharapkan untuk mengkaji tentang promosi dan pemasaran yang sekiranya cocok dan dapat dipergunakan oleh paguyuban onthel untuk memaksimalkan potensinya dalam melestarikan kawasan ini.

Peneliti juga hendak memberikan saran bagi Pemerintah Provinsi DKI Jakarta. Pemerintah Provinsi DKI hendaknya dapat memberikan bantuan pendidikan formal kepada para anggota komunitas lokal hingga setara SMA serta memaksimalkan bantuan pendidikan informal agar kualitas SDM memadai, serta memaksimalkan peran Satuan Pelaksana Pengawasan dan Penataan (Sat-Lak Wasta) UPK Kota Tua dalam fungsinya yaitu pengoordinasian, pembinaan dan penyebaran informasi kepada seluruh instansi, masyarakat dan kelompok lembaga swadaya masyarakat tentang nilai penataan dan pengembangan kawasan Kota Tua.

Terakhir adalah saran bagi Paguyuban Onthel Wisata Kota Tua. Disarankan agar paguyuban ini dapat memperbaiki manajemen komunitas agar dapat bekerja dalam sebuah tim, meminimalisir konflik internal, berani menindak tegas anggotanya yang tidak mengikuti aturan yang dibuat, dan selektif dalam memilih anggota. Diharapkan pula agar paguyuban onthel dapat membuat dan memaksimalkanberbagai akun di segala kanal media sosial yang ada seperti facebook, twitter, instagram serta blog sebagai sentra informasi komunitas. Selain itu, paguyuban onthel juga dapat memaksimalkan potensi dan melegalisasi pemandu wisata yang telah dimiliki, serta lebih berinovasi terhadap rute wisata yang telah dibuat. 


\section{National Conference of Creative Industry: \\ Sustainable Tourism Industry for Economic Development}

Universitas Bunda Mulia, Jakarta, 5-6 September 2018

e-ISSN No: 2622-7436

\section{DAFTAR PUSTAKA}

Arida, Nyoman Sukma. 2016. Dinamika Ekowisata Tri Ning Tri di Bali. Denpasar: Pustaka Larasan.

Madiun, I Nyoman. 2010. Nusa Dua: Model Pengembangan Kawasan Wisata Modern. Denpasar: Udayana University Press.

Pemerintah Provinsi DKI Jakarta. 2007. Perda No. 8 Tahun 2007 Tentang Ketertiban Umum. Jakarta: Pemerintah Provinsi DKI Jakarta.

Pemerintah Provinsi DKI Jakarta. 2014. Pergub No.36 Tahun 2014 Tentang Rencana Induk Kawasan Kota Tua. Jakarta: Pemerintah Provinsi DKI Jakarta.

Pemerintah Republik Indonesia. 1992. UU No. 5 Tahun 1992 Tentang Benda Cagar Budaya. Jakarta: Pemerintah Pusat Republik Indonesia.

Pitana, I Gede. 2009. Pengantar Ilmu Pariwisata. Yogyakarta: Penerbit Andi.

Putra, I Nyoman Darma. 2015. Pariwisata Berbasis Masyarakat Model Bali. Denpasar: Magister Kajian Pariwisata, Universitas Udayana.

Riadi, Dodi. 2015. Kerangka Pembangunan Destinasi Kota Tua Jakarta. Jakarta: DMO Kota Tua Jakarta.

Antara News. 2013. "Berwisata Dengan Sepeda Onthel di Kota Tua", sumber:

http://www.antaranews.com/berita/400159/berwisata-dengan-sepeda-onthel-di-kota-

tua(Diakses pada 18 Agustus 2018)

Tempo. 2015. “'Manusia Batu’ Itu Pun Ikut Bersih-bersih”, sumber:

https://metro.tempo.co/read/news/2015/05/17/083666839/manusia-batu-itu-pun-ikut-

bersih-bersih(Diakses pada 18 Agustus 2018) 